\title{
Probable Control Status
}

National Cancer Institute

\section{Source}

National Cancer Institute. Probable Control Status. NCI Thesaurus. Code C99272.

The participant is a probable control for the phenotype under consideration. 